largest, and then follows a copy of the scales of rates for the purchase of deferred annuities published by that company, and two further tables. combining annuity and life premiums. We are rather disappointed not to be directed to the special advantages claimed for nurses. We think this a point which should be most clearly expressed ; to what end is the fact of their being contributors to the "Record"? and why the threepence to the editor for a form of application, which, we apprehend, would be hastily supplied by the Prudential Company on receipt of a post-card, or at the slightest intimation to any agent?

The "sick-pay" scheme appears to be the result of an arrangement with the Sickness and Accident Assurance Association, Limited, of Edinburgh, and here again we fail to find any statement or indication of special terms to nurses.

Assurance against sickness necessitates the embodiment of so many stringent conditions, and so much provision against ulterior motives and possibilities, that it has hitherto proved an extremely difficult problem to set forth a scheme at once safe to the promoters and acceptable to the public. The Prudential and other large societies have long since discarded this class of business for very good reasons, and it is a remarkable and important fact that a very large majority of the friendly societies assuring against sickness are brought out absolutely insolvent on actuarial investigation, so that we do not yet find ourselves in a position to give any encouragement to sickness assurance on the one hand or the other.

With regard to both these schemes, the "Record" certainly states in an explicit manner that they are strictly provident and business arrangements, and that no claim whatever is made to charity or philanthropy.

\title{
NEW PREPARATIONS.
}

\section{Sedox.}

THIS material, which is prepared from pure vegetable fibre, has been submitted to careful tests by us, and we can say of it that it is as efficient and clean a surgical dressing as we are acquainted with. Taking up fifteen times its own weight, it possesses remarkable absorbent powers. It can be readily medicated with any of the ordinary antiseptics. For cleanliness, efficiency, and absorbent properties, it is without doubt unrivalled by any of the other absorbent wools.

\section{Balcomb's Books and Clinical Diagrams.}

A SERIES of gummed diagrams, perforated at the margins for ease of detachment, is here presented, which cannot fail to be of great use as accessories to the ordinary clinical note records. These diagrams represent accurate reproductions of the ordinary anatomical appearances of the larynx, fauces, and naso-pharynx. They have also the merit of exceeding cheapness. We can highly recommend them for the purpose for which they are intended

\section{NOTE.}

Sir WiLliam DaLby, having completed his term of twenty years as Aural Surgeon to St. George's Hospital, is now retiring from the post. 


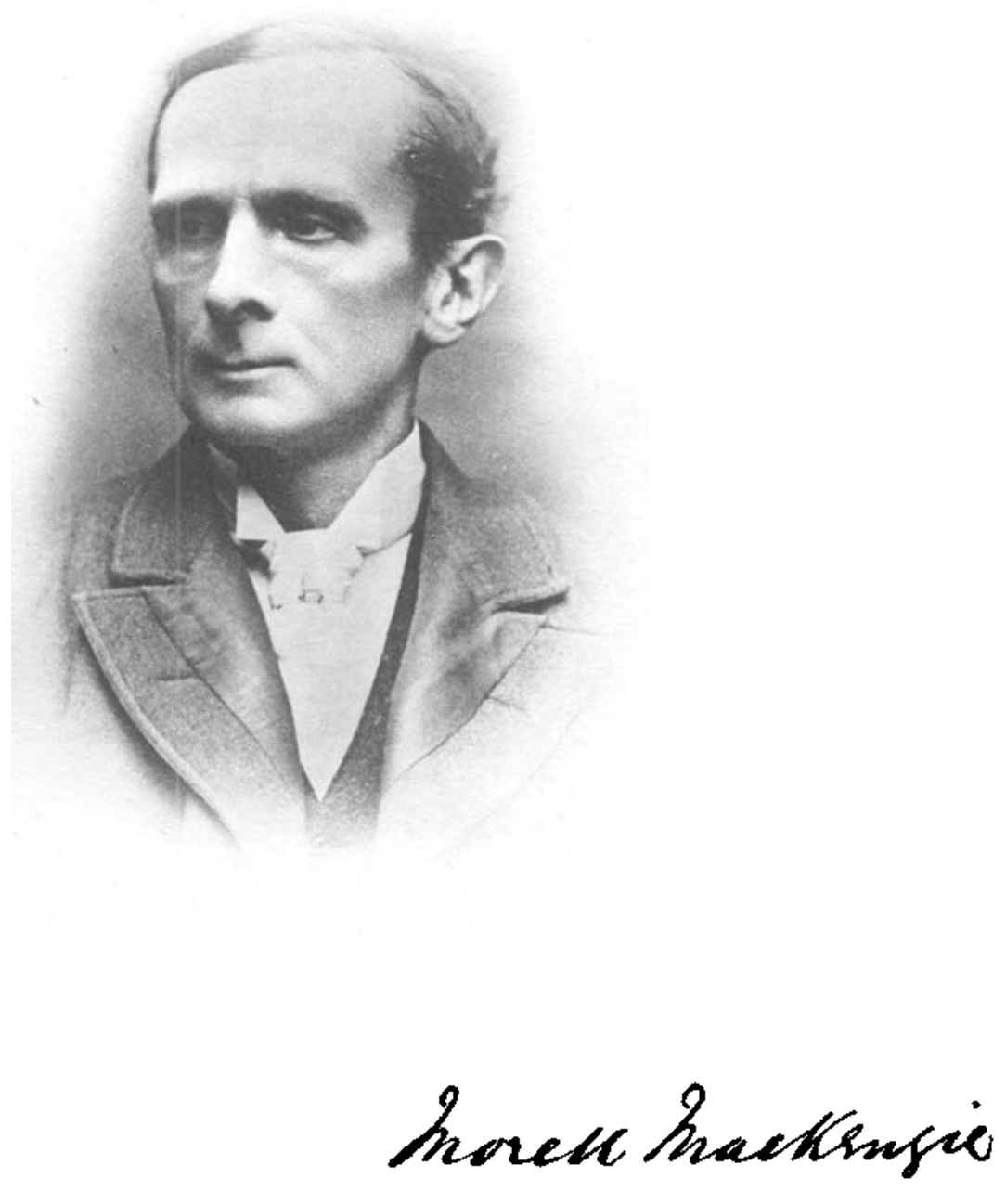

From a Photograph taken on 15th December, 1891, by Elliott $₫$ Fry, Reproduced by the Graphotone Company, Bush Hill Park, Enfield, Middlesex. https://doi.org/10.1017/S1755146300161670 Published online by Cambridge University Press 


\section{INDEX TO VOL. VI., 1892.}

A.

Abscess-bronchiectatic, 169; cerebral, 31, 408, 468, 587 ; cerebellar after ear disease, 468,587 ; extra-dural, 178 ; afser otitis, 179; idiopathic of larynx, 207 ; laryngeal, 120 ; retro-pharyngeal, 257,572

Actinomycosis-of larynx, 263; of lip, 298

Adenoid vegetations--in deaf and duml, $16,75,76,254,529$

Adenoma sebaceous, 73

Agents-altitude, 295 ; anæsthetics, 508 ; antidiphtheriticon, 274 ; antipyrin, 35, I I2 ; aniline colour, 361 ; aristol, 8,142 ; atropine, 68 ; boracic acid, $55^{\mathrm{I}}$; brom-ethyl, 142, 246, 500 ; camphorated naphthol, 443 ; cantharidinic salts, 82 ; cantharidinum, 294, 5 I 8 ; carbolic acid, 275, 321 ; chloroform, 69 ; chromic water, $7 \mathrm{I}$; cocaine, 68, $69,1_{42}, 512,585$; compressed air, 490 ; creosote, 262, 454; creosol iodide, 8 ; dermatol, 9 ; dog's serum, 9 ; ether, 283 ; europhen, 9, 453; guaiacol and iodoform, 9 ; iodide of potassium, 496 , 50I ; iodine, $275,295,453$, $45^{6}$; liq. ferr. sesquichlorate, 251 ; massage, 238, 573; menthol, 128 ; mercury, 276, 589,609; metallic mercury, 268 ; myrrh, 518 ; nitrate of silver, 295 ; potassium iodide, 92 ; potassium permanganate, 250 ; pyoktanin, 70 ; salicylic acid, 71 ; salol, 33 , II2, 470 ; savin and tannin, 34I ; sedox, 94 ; sulphite of calcium, 392 ; sulphur and quinine, 294 ; tannate of mercury, 68 ; trichloracetic acid, $8,43^{2}$; tuberculin, 9,281 ; turpentine, 455

Air passages - their diseases (Douglas), I3; surgery, I3, I70; after influenza, 176

Anatomy-middle ear, 235

Aneurism-aortic, 23 ; rupture into œsophagus, 80

Angina-lingual phlegmonous, I35; ulcerosa benigna (Sedziak), 335

Annotations-appointment, I6I ; a new nasal speculum, $5 \mathrm{I} 8$; cycling and laryngitis, 157; programme of the British Laryngological and Rhinological Asssociation meeting, 160; the Dublin Throat Hospital, 517; the mode of closure of the larynx, I 58 ; the pneumatic speculum as a routine instrument, 6 ; the treatment of diphtheria, $15^{8}$; the value of specialists, 7

Anosmia, 253

Antipyrin-local anæsthesia with, 35

Antiseptics-mouth, 77

Antrectomy, 3io

Antrum - empyema of, 42 ; illumination of, 162 ; empyema resulting from erysipelas, 162, 297 ; alsscess, 396, 397

Aphasia, $5^{80}$

Aphonia-hysterical, 580

Aristol--in aural and nasal disease, 8

Association Meetings--

American Laryngological As sociation-A Case of Epithelioma of the Larynx (Asch), 92; A Case of Foreign Body in the Trachea (Glasgow), 90 ; A Case of Thyrotomy in a Child eighteen months old (Wagner), 90 ; A Study of a Case of Nasal Tuberculosis (Shurly), 9r; Cysts of the Middle Turbinated Bone (Knight), 91: The Laryngo-Tracheal Neoplasm of Tuberculosis (Mackenzie), 92 : The Radical Treatment of Nasal Myxomata (Casselberry), 92; The Symptoms and Pathological Changes in the Upper Air Passages in Influenza (Solis-Cohen), 92 ; The Tonsils in Health and Disease (Harrison Allen), 90; The Troublesome Symptoms caused by Enlargement of the Epiglottis, and the advisability of reducing the size of this Cartilage by Operative Measures (Rice), 90; The Various Forms of Ethmoid Disease (Bosworth), 91; A Case of Fibrous Epithelioma at the Ront of the Tongue (Wright), 540 ; A Case of Suppurating Ethmoiditis (Bryan), 545; Adenoid Forceps (Farlow). 544 ; A Safe Nasal Doucbe (Grant), 433 ; A Safe EndoLaryngeal Forceps (Grant), 433; Clerg) man's Sore Thioat (Browne), 437 ; Granular Pharyngitis : its Etiologg and 
Treatment (Hovell), 434 ; Intubation for Chronic Stenosis in a Boy (Knight) 542 ; New Method of Administering Iodide of Potassium, etc. (Delavan), 541 ; On the Influence of Certain Diathetic Conditions upon the Prognosis in Operations upon the Throat (Delavan), 538 ; Pharyngo-mycosis (Knight), 540 ; Presentation of Instruments, 54I; Rare Forms of Laryngeal Growth (MacCoy), 542 ; Report of some Cases of Membranous Sore Throat (Robinson), 541 ; Some Pathological Conditions of the Upper Air Passages coincident with Attacks of la Grippe (Chapman), 339; The Importance of guarding against Injury to the Middle Ear when Treating the Nasal Passages and Nasopharynx (Barr), 437; The Correction of Deformity resulting from Abscess of the Nasal Septum (Roe), 544; The Value of Sprays in the Treatment of Catarrhal Affections of the Upper Air Passages (Rice), 543; The After Results of Nasal Cauterization (Blois), 544; Tumours of the Larynx (Swaine), 543.

American Medical AssociationA Case of Abductor Paralysis of both Vocal Cords (Wright), 472; A Case of Papilloma of the Epiglottis, etc. (Thrasher), 492 ; A Case of Papilloma of the Larynx (Waxham), 477 ; A Case of so-called Bezold variety of Mastoiditis (Knapp), 472; A Case of Spastic Contraction of the Tensor Tympani Muscle (Richardson), 493 ; A Note on the Etiology of Laryngismus Stridulus (Roe), 595; Abstract of Observation of 25 Cases of Ear Disease occurring as Sequelre to Epidemic Influenza in San Francisco between r889-92 (Toole), 484; An Improved Galvano-Cautery Snare; its use in the Nose and Throat (Loeb), 48I ; Catarrhal Sore Throat in the Lake Region (Carter), $49 \mathrm{I}$; Compressed Air in Diseases of the Nose, Throat, and Ear (Scott), 490 ; Diseases of the Naso-Pharyngeal Portion of the Respiratory Tract, their Relations to, and Ulterior Effects upon the General Health (Jenson), 483; Hypertrophy of the Anterior Extremity of the Middle Turbinate Body of the Nose (Woolen), 491 ; Infectious Pseudo-membranous Follicular Tonsillitis and Pharyngitis (Casselberry), 479; Mastoid Trephining, with 32 cases operated on among 3400 new ear patients of 1889 to I $89 \mathrm{I}$ (Randall), 480; Mental Aberration attending Hypertrophic Rhinitis with Subacute Otitis Media (Carpenter), 478 ; Naso-Pharyngeal Lesions due to
Lateral Vaso-Motor Causes (Seiss), 473 ; Peroxide of Hydrogen and its use in Ear Diseases (Johnson) 487; Some Observations upon Excision of the Membrana Tympani and the Two Largest Auditory Ossicles (Burnett), 474; Spontaneous Cure of Multiple Papillomata of the Larynx after Tracheotomy (White), 486; Synopsis of article on Excision of the Membrana Tympani and the Two Larger Auditory Ossicles, etc. (Burnett), 475 ; The Medical Treatment of Acute Tonsillitis and Pharyngitis; a comparative study based on 169 cases (Newcomb), 470; The Operation for Excision of the Ossicula in Chronic Aural Catarrh with Instance of a Failure (Wurdemann), 489; The Physiology and Pathology of the Tonsils (North), 487 ; Tuberculosis of the Pharynx (Boylan), $47 \mathrm{I}$.

American Otological Society-A Case for Operation for Catarrhal Deafness (Randall), 533 ; Acute Suppuration of the Middle Ear (Ray), 48; Anatomy of the Elephant's Ear (Richards), 49; Antiseptic Solutions in Purulent MiddleEar Disease (Theobald), 55I ; Basilar Meningitis occurring in a Case of Chronic Purulent Otitis Media (Knapp), 547; Craniometric Studies in Relation to Aural Anatomy (Randall), 548 ; Dislocation of the Malleus Handle (Theobald), 49 ; Excision of the Membrana Tympani and Necrotic Malleus for Chronic Purulent Otitis Media (Burnett), 48; Fxostosis of the External Auditory Meatus (Roosa), 533; Free Opening of the Mastoid and Removal of all Diseased Tissue (Blake), 47; Mastoid Cases (Blake), 549; Mastoid Inflammation (Knapp), 47; Mastoid Operation (Sutphem), 550; Mastoid Disease following an Operation for the Removal of Adenoid Vegetations (Bacon), 55०; Middle-Ear Operation (Blake), 552); Otitic Epilepsy, Trephining and Fatal Septic Meningitis (Randall), 48; Otitis Media and Optic Neuritis (Kipp), 549 ; Pyamia following Acute Suppurative Otitis (Emerson), 549; Remarkable Improvement in Hearing following Removal of the Stapes (Jack), 55I ; Seven Cases of Mastoid Diseases exhibiting somewhat extensive Carious Processes (Pomeroy), 546; Tympanic Membrane (Theobald), 48 ; Use of the Leiter Coil in Mastoid Disease (Bacon), 48.

American Pediatric AssociationForms of Diphtheria which simulate simple Angina, 325.

Annual Meeting of Belgian Laryn- 
gologists and Otologists, Liege-A Bone removed from the Larynx after Tracheotomy (Koch), 344; Abscess of the Trachea (Hicguet), 345 ; A Manubrium Mallei expelled from the Ear in a Clot of Blood (Rutten), 344 ; Circumscribed Dilatation of the Upper Portion of the Esophagus (Schiffers), 342 ; Corradi's Tuning-Fork Test (Eeman), 344; Fenestrated Forceps for removing Spurs from the Septum (Rousseau), 344 ; Fibrous Polypus (Capart), 342 ; Gum Elastic Sounds made rigid by a Lateral Mandarin (Delstanche), 343; Mycotic Affection of the Throat (Capart), 342; Operation for Naso-pharyngeal Polypus (Bovat), 347; Papillomatous Vegetations of the Larynx (Schiffers), 341 ; Pemphigoid Bullous Eruption of the Larynx (Wagnier), 343 ; Primary Epithelioma of the Larynx: Intubation, Tracheotomy, Laryngectomy, Artificial Larynx (Bayer), 343; Rhinoplastic Operation for an Enormously Hypertrophied Nose (Delie), 342 ; Specific Disease of the Larynx (Schiffers), 342 ; The Angina following Mercurial Treatment (Schuster), 344; The Employment of Liquid Vaseline in Affections of the Middle Ear (Delstanche), 343; The Mastoid Antrum in the Child (Laurent), $34^{6}$; The Prodromal Affections of the Respiratory Apparatus in Typhoid Fever, Typical Pharyngeal Ulcerations (Bayer), 344 ; Two Cases of Mastoid Abscess with Perforation of the Median Wall (Bezold's) following Influenza: Recovery (Moll), 346; Whispered Voice as a measure of Hearing Power (Eeman), 345.

Berliner Medicinische Gesellschaft -Etiology of Diphtheria (Baginsky), I74.

British Laryngological and Rhinological Association--A Case of Deep Abscess of the Neck followed by Acute Laryngeal Symptoms : Tracheotomy (Ward Cousins), 208; A Case of Rodent Ulcer extending from the Face into the Superior Maxillary Bone (Macintyre), 362; Characteristics (Histological) of Laryngeal Epithelioma (Wyatt Wingrave), 2I5; Hypertrophic Rhinitis with old history of Lupus (Browne), 203 ; Lupus of the Nose, Pharynx, and Larynx (Browne), 204 ; Idiopathic Abscess of the Larynx (Milligan), 207 ; Csophageal Obstruction by a Dental Plate, Extraction three and a half years subsequent to the accident (Browne), 365 ; The necessity for Systematic Voice Training in Public Speakers (Sandford), 2I5; On the Etiology of
Affections of the Upper Respiratory Tract (Macintyre), 369; Primary Nasal Syphilis-Second Attack of Syphilis (Milligan), 205; Some Points concerning the Lingual Tonsil bearing upon a Regional Nomenclature of the Tongue (Wyatt Wingrave), 213; Two Cases of Glosso-labio-laryngeal Paralysis (Sandford), 2 I I T The Relations between the various forms of Nasal Stenosis and Deafness (Bendelack-Hewetson), 377.

British Medical Association(Laryngological Section)-Etiology, Pathology, and Treatment of Catarrh of the Nose and Throat (Macintyre), 4I8; The Dyspeptic Sore Throat (Wilkams), 432 ; The Etiology, Pathology, and Treatment of Nasal Neurosis (Stewart Browne), 4I6; Faults in Voice Production which lead to Throat Disease (Browne), 428 ; Nervous Disease of the Throat (Schrötter), $4 \mathrm{I} 7$; On Loss of the Singing Voice (Hunt), 430; On Trichloracetic Acid in the Treatment of Ozæna (Bronner), 432 ; On the Importance of a Systematic Course of Physical Voice-Training, at School and College, with regard to its influence on prevalent Throat Troubles in Public Speakers and others (Sandford), 423; Practical Points in the Diagnosis and Treatment of "Fish Bones in the Throat" (Dundas Grant), 432 ; A Safe Nasal Douche (Grant), 433 ; A Safe Endo-Laryngeal Forceps (Grant), 433 ; The Treatment of Ozana and Recurrent Nasal Polypi by opening and draining Highmore's Antrum (Robertson), 43 I.

First Meeting Italian SocietyActinomycosis of the Tongue and Iarynx (Maiocchi), 609; Bacteriological Consideration in Ozæna (Strazza), 609; Case of Hysterical Mutism (Ficano), 609 ; Chronic Nasal Glanders (Poli), 609; Cicatricial Hypoglottic Stenosis (Massei), 609 ; Clinical Studies on Oziena (Morra), 609; Clinical Studies on the Symbiosis of Laryngeal Syphilis and Tuberculosis (Fasano), 607 ; Deviations of the Nasal Septum and their Treatment (Dionisio), 608 ; Diseases of the Labyrinth and their Diagnosis (Masini), 6I I ; Diphtheritic and Scarlatinal Sore Throat (Fiaccarini), 609; Epithelioma of the Larynx (Egidi), 606 ; Epithelioma of the Left Tonsil (Marano), 607 ; Eighty-two Intubations and as many Tracheotomieş (Egidi), 609 ; Enpyema of the Antrum of Highmore (Nicolai), 609; Functional Energy of the Acoustic Nerve, \&c. (Gradenigo), 610; Nasal Tuberculosis (Dionisio), 
608 ; On Mercurial Treatment in some so-called Nasal Scrophulides (Fasano), 6o9; On the Diagnostic Importance of the Perception of Sounds by Perosseal Aerial Conduction in Diseases of the Ear (Corradi), 6ro; On the Functions of the Otologist and Laryngologist in Institutions for the Deaf and Dumb (Gradenigo), 6I I ; Oral and Pharyngeal Pemphigus (Garzia), 607; Pachydermia Laryngis-a Histological Note (Damieno), 606 ; The Diagnosis and Treatment of the Diseases of Accessory Cavities of the Nose (Strazza), 607; The Importance of Laryngology, Otology, and Rhinology in Medical Practice-Considerations and Propositions (Trifiletti), 605; Therapeutic Contribution upon the Otorrhoeas of Scrofulous Subjects, and on Crusting Chronic Rhinitis (Isaia), 609; The Laryngeal and Tracheal Phenomena of Gout (Ajello), 606; The Phases, Nature, and Therapeutics of Papillomata of the Larynx (Massei), 605; Treatment of Large Naso-Pharyngeal Tumours (Massei), 609; Two Cases of Chronic Croup (Egidi), 609.

French Society of Laryngology and Otology-A Case of Crico-arytenoid Arthritis (right side) due to Tertiary Syphilis (Natier), 50I ; A Case of Infectious Angina (Ferras), 497 ; Abscess ot the Larynx consecutive to Scarlatina (Moure), 498 ; A Rare Case of Ulceration of one Vocal Cord (Vacher), 32 I ; Adenoid Tumours, Two Successive Recurrences in one Case, and one Recurrence in another (Lavrand), 320 ; A little known Affection of the Tonsils (Hicguet), 499 ; A New Case of Indurated Chancre of the Left Nasal Fossa (Moure), 496 ; Bromide of Ethyl as an Anasthetic (LubetBarbon), 500; Cachexia Strumipriva, with complete Paralysis of the Right Vocal Cord and Paresis of the Ieft Vocal Cord, consecutive to Ablation of the Thyroid Gland (Natier), 502 ; Concerning Operation for Adenoid Vegetations of the Nasal Pharynx (Rousseau), 323; Electrolysis of the Nasal Fossa with Electrodes of a New Model (Garrigou-Desarenes), 495 ; Fversion of the Ventricle of Morgagni (Beausoleil), 497 ; Inter-Arytenoidean Fuso-Cellular Sarcoma-Operation per vias naturales Cure lasting eight months-Recurrence -Tracheotomy(Delie), 32 I ; New Nasal Speculum (Moure), 503; On a New Mode of Treatment of Syphilis, and especially of severe Syphilis of the Nasal Fossæ by administration of the iudides of potassium, soda, and ammoniaadvantages of this process, etc. (Daryus), 496 ; On a New Symptom of Laryngeal Paralysis (Fauvel), 493; On the Treatment of Rebellious Suppuration of the Maxillary Sinus (Cartaz), 494; On some Inconveniences of the Nasal Douche and on the means of avoiding them (Suarez de Mendoza), 5or ; Rarity of Cortical Laryngeal Paralysis (Raugé), 318; Sarcoma of the Tonsils--difficulty of Histological Diagnosis (Luc), 320 ; Stereoscopic Photography in the Normal and Pathological Anatomy of the Larynx and Nose (Garel), 502 ; Syphilitic Condylomata of the Nasal Fossae (Lacoarret), 497 ; The Spray in the Treatment of Diphtheria, with presentation of an apparatus (Polo), 321 ; The Treatment of certain Strictures of the Nasal Fossa (Asteir), 348 ; The Treatment of NasoPharyngeal Fibro-Myxomas (Wagnier), 322 ; Tonsillar Fever and Purpura (Joal), 349; Two Cases of Lupus of the Larynx (Garel), 317.

Gesellschaft der Aerzte des Canton Zurich-Contribution to Rhino-Pathology (Suchannek) 277.

Medical Society of the State of New York-Diphtheria, with Special Reference to a New Method of Treat ment (Martindale), 176; Fibroids of the Naso-Pharynx and their Treatment by means of the Electro-Cautery (Goodwillie), 177

New York Acadamy of Medicine-Case of so-called Laryngeal Vertigo or Laryngeal Epilepsy (Phillips), 276 ; Case of Stenosis of the Larynx following Fracture-Treated by Intubation (Stim. son), 277 ; Intubation $\%$. Tracheotomy for Acute Laryngeal Stenosis in Children-To what extent, if at all, has Intubation supplanted Tracheotomy (O'Dwyer), 599; On Hypertrophy of the Tonsils (Asch), 277 ; Superior Maxillary Neoplasm Removed by Rouge's Opera. tion (Chappel), 276.

Otological Section of the Sixty-fourth Gathering of the Association of German Naturalists and Physicians-A Case of Extensive Nerve-Degeneration in all the Turns of the Cochlea (Scheibe), 46 ; A Case Operated on by the Author's Modification of Stacke's Method (Kretschmann), I40 ; A Case of Multiple Exostoses of the Cranium, with Unilateral Atrophy of the Face: Demonstration of the accompanyingr Aural Exostoses (Krakauer), I4I ; An Otitic Cerebral Abscess cured by Operation (Truckenbrod), 45 ; Casuistic Communications (Szenes), I43; Cholesteatoma 
(Schwartze), I40; Contribution to the Excision of the Malleus and Incus (Reinhard), 89; Demonstration of an Apparatus for procuring Germ-free Water for Syringing (Brieger), I79; Demonstration of Casts and Dried Preparations(Siebenmann), I 40 ; Extraclural Abscess in the course of Middle Ear Disease (Hecke), 178 ; Further communications on the Operative Exposure of the Cavities of the Middle Ear after Separation of the Auricle (Stacke), 87 ; Instances of Recovery from Metastatic Pyæmia arising from Middle Ear Disease (Hecke), 178; On Affections of the Middle Ear in Lupus of the Nose (Brieger), 45; On Disease of the Organs of Hearing following Tabes Dorsalis (Habermann), 46; On Extra-dural Abscesses following Otitis (Hessler), I 79; On the Accord between the Galvanic Reactions of the Eye and Ear (Kiesselbach), 44; On the Therapeutic Effects of some new Otiatric Remedies (Szenes), I42; On the Treatment of Blennorrhoea of the Middle Ear (Loewe), 177 ; On the Use of Lucae's Spring Pressure Probe in Diseases of the Middle Ear (Walb), 143.

Paris Society of Laryngology, Rhinology, and Otology-A New Process for the Catheterization of the Eustachian Tube (Loewenberg), 444; The Nasal Douche and its indications (Percepied), 440; The "Otic sign" in Cerebral Affections: Value of the Binauricular Accommodative Reflex (Gellé), 437 ; Statistical Note on Suppuration of the Middle Ear complicated with Mastoid Inflammation (Hamon du Fougeray), 442.

The Society of Laryngology and Rhinology of Paris-A Case of Acute Rheumatic Crico-Arytenoid Arthritis (Luc), I9I ; A Case of Deafness due to Mumps (Gellé), 35; An Apparatus for giving Insufflations of Antiseptic Air or Medicated Vapours and Injections into the Tympanic Cavity through the Eustachian Tubes (Gilles), 229; A Case of Foreign Body in the Ear (Ménière), 35I ; A Case of Foreign Body (piece of peach) which remained for three days in the Nasal Pharynx (Saint Hilaire), I93; A Case of Subglottic Polypus (Papadapoulos), 43; A Leech in the Larynx (Aubert), 44; A Note on Contraction of the Transverse Arytenoid Muscle (an endeavour to interpret the Laryngoscopic signs attributed by Gerhardt to "bilateral and complete paralysis of the posterior crico-arytenoid muscles") (Ruault), 350; Bilateral Paralysis of the Posterior Crico-arytenoid in a Case of Aneurism of the Aorta (Cartaz), 37 ; Calculus of Wharton's Duct (Chatellier), 349; Carcinoma of the Left Vocal Cord-Laryngo-fissure (Lichtwitz), 39 ; Case of Adenoid Granulations in an Infant six weeks old (Astier), 554; Critical Study on the Etiology of Deviatinns of the Septum, with Presentation of a Specimen (Potiquet), 313 ; Demonstration of the Local Anxesthetic Properties of Antipyrin--its Employment in certain Affections of the Throat and Lungs (St. Hilaire), 35 ; Eczematous Erythema consequent upon Application of Salol (Cartaz), 33; Extirpation per vias naturales of Multiple Papilloma of the Larynx in a Child by a New Method - Intubation with a Fenestrated Tube (Lichtwitz), 315 ; Extensive Perforation of the Septal Cartilage of the Nose in Typhoid Fever (Gellé), 35 ; Foreign Body in the Larynx (Gouguenheim), 36 ; Foreign Bodies and Cornified Productions of the Pharynx in Pharyngo-mycosis-Action of Iodated Chloride of Zinc on Leptothrix Buccalis (Nabias and Sabrazes), 558; Glandular Retention Cysts of the Anterior Part of the Nasal Fossæ (Chatellier), 182; Hemi-Anasthesia of the Face, Head, land Organs of Sense in the course of Otorrhcea (Gellé), 3I3; Ménière's Vertigo, Pulsations demonstrated by the Endotoscope indicating Otitis (Gellé), I80 ; Naso-Lobar Neuralgia, symptomatic Tertiary Nasal Syphilis (Gellé). 43 ; Note on the Treatment of Pharyngitis of the Vault or Tornwaldt's Angina (Lubet-Barbon), I86; Note on the Treatment of Catarrh of the Pharyngeal Tonsil and particularly the circumscribed form called Tornwaldt's Angina(Ruault), 184; On a little known Variety of Phlegmonous Angina (Lingual Phlegmonous Peri-Amygdalitis: Superficial Submucous Phlegmon of the Base of the Tongue, (Ruault), I35; Observation to serve for the Study of Laryngeal Neuropathic Stenosis (Ruault), 36; On the Anatomy of the Middle Ear (Chatellitr) 233; On the Opening of the Mastoid Process in Cases of Acute Median Otitis following Influenza, 352 ; On the Therapeutical Use of the Soluble Salts of Bismuth, especially in Otorrhea (Garnault), 360 ; On the Frequency of Latent Bilateral Empyema of the Antrum of Highmore, and the Necessity of Methodical Exploratory Irrigation of this Cavity in Cases of Nasal Blennorrhoea (Lichtwitz), I87; Researches on the Anatomical 
Causes of Deviation of the Nasal Septum, etc. (Potiquet), 596; Suppurative Otitis and Cerebral Symptoms after Posterior Tamponing for Severe Epistaxis (Gellé), 40; The Thickening of the Antero-Inferior Portion of the Nasal Septum-Róle of the Subvomerine Bones and the Cartilages of Jacobson (Potiquet), 597 ; Two Cases of Cure of Chronic Suppuration of the Tympanum by Excision of the Malleus (Luc), $3^{8}$; Two Cases of Foetid Empyema of the Maxillary Sinus without Apparent Dental Alteration (Luc), 42; The Treatment of Tracheitis by Hot Inhalations of Menthol (Martin and LubetBarbon), 128; The Canal of Jacobson, and the possibility of recognizing it during life, and its probable role in the pathogenesis of certain lesions of the Nasal Septum (Potiquet), I29; The Use of Injections of Van Swieten's Liquor into Tissues of Cancerous Appearance (Marage), I 92.

Versammlung Deutscher Naturforscher und Aerzte in Halle-a-S. - A Modified Laryngeal Mirror (Harke), 362 ; A Method of post-mortem Examination of the Nose and Appendices without External Malformation of the Cadaver (Harke), 362 ; Apparatus for Laryngo-Photography (Wagner), 362 ; Electrolytic Treatment of Hypertrophic Catarrh of the Nose (Flatau), 362; Instrument to prevent the falling in of the Ale Narium (Schmidthuyzen), 362; Laryngoscopical Apparatus with Auer's Incandescent Light (Wagner), 362 ; Melano-Sarcoma of the Nose (Heymann), 36I; On Cysts on the Vocal Bands (Chiari), 361 ; On the Application of Aniline Colours in Diseases of Nose, Throat, and Ear (Bresgen), 361; Photographs of Microscopic Specimens : Vertical and Horizontal Sections of the Human Larynx (Fraenkel), 36r ; Removal of the Canula and Treatment of Laryngeal Stenosis following Tracheotomy in Children (Thost), 362 ; Treatment of Pachydermia Laryngis (Scheinmann), 362; Treatment of Rhinitis Atrophica Foetida (Flatau), 362.

Asthenopia - and hypertrophic rhinitis, 117,396

Asthma-treatment of air passages for relief, $91,458,57^{6}$

Astigmatism and coryza, 395

Attic suppuration, 87, 122

Auditory centre, 173

Aural-complications in head injuries, 468 ; aristol in affections, 8 ; disease and rules for trephining, $27 \mathrm{I}$; polypi, 268 , 309,467

Auricle-epithelioma of, 463
B.

Basedow's disease-treatment in, 93, 266

Black tongue, I 7

Blennorrhoea of lac. sac, 297 ; middle ear, 177

Brain, disease of-after nasal operation (Wagner,) 74

Breathing, correct, in voice production, 242

Bronchocele, 25

Bursa pharyngea-disease of (Chiari), I 5

\section{c.}

Calculus-in sub-maxillary gland, 526 ; in Wharton's duct, 527

Cancroid of larynx, 582

Cantharidinic salts-effects of, 82 ; in diphtheria, 294

Carcinoma-injection of mercury in, 192

Caries, cervical, I 18

Catarrh-general versus local treatment, 70 ; acute, 167 ; chronic pharyngeal, 393

Cautery-electro-thermo, 67

Cerebellar tumour, 33

Chloroform - accidents and treatment of, 69; death under, 69; Junker's inhaler modified, 245

Cholesteatoma of ear, 30 ; treatment,

31,140

Chorea, laryngeal, 263, 305

Cocaine-use and abuse of, 512

Congenital--auditory malformation, I 48, 536 ; goitre, 17 ; macroglossia, 17 ; occlusion of post nares by septum, 75 ; palatal defects, 256 ; replacemient of absence of meatus, 171

Consumption-condition of cure, 8 ; hypodermic administrations, 9

Cough, nervous laryngeal, i 20

Creosol iodide in naso-pharynx and larynx, 8

Croup-diphtheritic, 12 ; practical considerations (Verstracten), I2 ; spasmodic, 295 ; tracheotomy in, 12

Cysts, 396 ; nasal fosse, 182 ; retrotympanic, 233

\section{D.}

Deaf-mutism, 272, 409; following scarlatina, 410

Deafness-duetosyphilis (hereditary), 308,337 ; microphone in, 271 ; in mumps, 34 ; surgical treatment of, 586 ; traumatic, 173

Diphtheria, 249, 295; anatomical research in paralysis, II ; bacteriological 
investigation in pneumonia with, II ; bacillus Loeffler, 520; case of, II ; cure of, 71 ; diagnosis of, 250 ; drainage and, $25 \mathrm{I}$; dysentery in, $7 \mathrm{I}$; etiology, 10, 174, 249, 251; experimental researches (Welch-Flexner), I1 3 ; gangrene of lungs, 295; high altitudes in, 71,296 ; intubation in, 12 ; irrigations of salicylic acid in, 71 ; muscular changes in, 295; myocarditis diphtheritica acuta, I 15 ; nervous symptoms, early, 250 ; organisms in, 522 ; paralyses in, I I, 295; propagation of, ro ; pseudodiphtheritic bacillus, I I4, 522 ; studies in human (Tangl), II ; treatment of, 12, 71, 1 13, 158, 176, 250, 25 I, 455; operative, 252 ; permanganate of potash in, $25^{\circ}$; typhoid fever followed by, 251

\section{E.}

Ear-audible noises in, 27 ; affections after nasal operation, 74 ; blows on, 27 ; congenital malformation, 148, 536 ; cocaine in, 585 ; diagnosis of internal and middle ear affections, $27 \mathrm{I}$; excision of small bones, 89; of membrane and ossicles in chronic suppuration of attic, 464 ; examination of, 400 ; foetor in diseases, 407 ; foreign bodies, 403,589 ; complications in head injuries, 468 ; influenza and ear disease, 269 ; injury to, 269; malignant tumours of, I24; meningitis in disease of, 407; nasal affections and ear disease, 585 ; operative exposure of cavities of middle ear, 87 ; operation in chronic suppuration of middle ear, 405 , 586 ; outstanding, 87 ; perception of tone in disease, 308 ; prognosis in affections of, 404; serous transudation in middle ear, 404 ; traumatic affection of membrane, 402 ; in typhoid and ear affections, 587 ; tuning-fork in disease, 272

Eczema erythema after use of salol, 33 Electric light in antral disease, 64 , 112, $45^{8}$

Electrolysis in affections of the nose and throat, 256; in oesophageal stenosis, 573

Empyema-frontal sinus, 16 ; antrum, $3 \mathrm{I}, 42,408,468,578,5^{87}$; bilateral antral, 187

Epiglottis - operation in enlarged, 9o, 302, 394

Epithelioma - naso-pharynx, 75; tongue, 570

Ethmoid disease, 91

Exostoses, multiple, of ear, etc., 14I
F.

Facial paralysis, 19

Fauces-congenital defect, 256 ; perforation of, 456

Fibro-myxoma-naso-pharynx, I 5

Foreign bodies-in ear, 589 ; artificial teeth, 80 ; fish bones, 456 ; laminaria, II5; leech, 44; hæmorrhage (fatal) from, 457 ; in larynx, 22, 36, 168 ; in naso-pharynx, 193; in nostril, Ix5; cesophagus, 19 ; in pharynx, 256; in trachea, 534

\section{G.}

Galvanic reactions-accord between those of eye and ear, 44

Galvanism and electrolysis, 296

Gastrotomy, I21, I28

Glossitis superficialis (Miller), 526

Glosso-labio pharyngeal paralysis, I $65,2 \mathrm{I} \mathrm{I}$

Goitre (see also " Thyroid Gland ") cases (Helferich), 85 ; fistula-congenita, 267 ; ligature of thyroid arteries, 267 ; sub-sternal, 85

Guillotine-new, 67 ; improved, 118 , 391

Gunshot wounds-nose, 176

H.

Hæmatoma of ear without mental disease, 30

Hæmorrhage - from larynx, 26r, pharynx, 299

Hay fever, 163

Hearing in railway servants, 121

Herpes of larynx, I67

Hospitals, British and Irish, for nose and throat, 447

Hyoid bone-tumour of, 534

I.

Ichthyosis of tongue, $\mathbf{5 2 7}$

Influenza-changes in air passages after, $92,255,256,3$ or

Intubation-cases of, $13,169,264$, 304,583 ; in diphtheria, 12 ; and tracheotomy compared, 296

Instruments-catheter, 289 ; curette, 254, 519, 541, 573; ear instruments, 4 II ; electric light, $64,109,196,458$, 529; electrodes, $54 \mathrm{I}$; electro-thermo cauteries, 67 ; electricity, 326,362 , 518 ; electrolysis, $245,265,296,396$, $495,573,574$; galvano-cautery, 295 ; hot water bag, 67 ; inhaler, 245,321 , 
518 ; insufflator, 229 ; Leiter coil, 48 ; nasal ecraseur, 246 ; nasal douche, 440 ; nasal electrode, 394 ; nasal ointment introducer, 573 ; nose eleva tor, 253; probes for trichloracetic acid, 246; saw, 246; snare, $245,246,276$, 518; speculum, 246, 503; spray, 245, 481 , 519 ; syringe, 516 ; tampon, 541 ; tongue depressor, $39 \mathrm{I}$

Iodol-hypodermically in phthisis, 9

\section{J.}

Jacobson's canal-its diseases, etc., I 29

K.

Keratosis-circumscribed larynx, 8I

L.

Labyrinth-in diphtheria, 273 ; pilocarpin in deafness of, 585 ; tuberculosis of, 588

Laryngismus stridulus, 305

Laryngitis, acute, 20, 208; and cycling, 157

Laryn $x$-abductor paralysis bilateral, 290, 400; abscess of, I 20, 303 ; anatomy and physiology, 19; chorea of, 263, 305 ; cockle burr in, 168 ; epithelioma of, 92 ; Extirpation of, 19, 22, 83, 120, 121, 170, 266, 306, 401, 531 ; foreign bodies, 534,583 ; hæemorrhage, 261 ; hysterical abduction, 457 ; inflamed joints of, 305 ; keratosis in, 8I ; laryngo-fissure, 267; leech in, 44; mechanism of closure, 259 ; paralysis in infants, $53^{2}$; in traumatic neuroses, 533; sarcoma of, 399 ; stenosis, 83 , I 5,533 ; swallowing in relation to, 580 ; syphilis of, 21 ; traumatism of larynx, 582 ; tumour of cords, $260,306,398,457,521,582$; tumour of (larynx) malignant, 298 ; ulceration (simple) of, 400 ; ventricle, eversion of, 497 ; vertigo, $168,173,409,53.3$

Lead in ear - removal of with mercury, 589

Lip-malformation of, 524

Lipoma of neck

Locomotor ataxia-hearing in, 46

Lupus-affecting middle ear, 45; nose, 204 ; primary, 582

Lymphangioma, neck, ${ }_{5} S_{4}$

Lymphoma, 393

tympho-sarcoma, neck, 26
M.

Macrocheilia, 570

Macroglossia from angioma, $57 \mathrm{I}$

Malleus-dislocation of, 49

Massage -in chronic affections, nose, etc., 70; (Kellgren), 237 ; mucous membrane, I63 ; vibrations (Chiari, Laker), 573

Mastoid disease-abscess, 122, 269 , 589 ; Bezold variety, 467 ; Leiter coil in, 48 ; opening of antrum (Robertson), 568

Meatus-lony growths in, $2 \delta$; sarcoma in, 268

Membrana tympani-collapse of, $3 \mathrm{I}$; examination of, 122; excision of, 48 , 464,537 ; old perforation of, 48

Ménière's disease, 27I; after influenza, 32 ; a symptom of Bright's disease, 536 ; endotoscope for pulsations in, 180

Menstruation and throat disease, 263 , 574

Middle ear-acute suppuration, 48 ; followed by meningitis, I22 ; erysipelas of, 32 ; pyæmia following, 172 ; pyæmia and recovery, 178

- Model-nasal cavities (Siebenmann), 14

Mouth bacteria, 456, 524 ; and teeth during pregnancy, 524

Mouth breathing and enuresis nocturna, 17

Mycosis-aspergillus in antrum, 16 ; pharyngo-mycosis (Hemenway), 53

Myxoedema, 26, 85, 465; extract of thyroid gland, 265,584

Myxo-sarcoma-nose, I4

N.

Nasal - alae, insuction of, 115 ; asthma, 576 ; catarrh in children, 177 ; cavities and other microscopic structures, 573; cautery for (Vulpius), 8; cerebral disease after operations, 578 ; clamp forceps for, 8 ; disease and speech, 252 ; discharge retention, I; fracture, 577 ; hydrorrhea, 458 ; myxomata, 90 ; ointment introducer, 573 : relation of affection to ear, 459,585 ; eye, 252, 459; lachrymal disease, 297; spray 245 ; speculum (new), 518; stenosis, 163 ; and general health, 575 ; surgery, I63; tuberculosis, 91

Neck-rare tumour of, 86 ; necrosing ethmoiditis, 577

Nerves - experiment on superior laryngeal, 20; resection of inferior laryngeal in paralysis of posterior crico- 
arytenoids, 36; centripetal conduct of same, 305

Neuralgia, facial, II 2 176

Neuroses-common, 73; traumatic,

Noises audible in ear, 27

Nose-apparatus (rubber) for straightening, 163 ; trichloracetic acid in nose and naso-pharynx, 8 ; tumours of, going to orbit, 161

Nystagmus of vocal bands, 168

\section{o.}

Occlusion of nose, I4; congenital, 529

CEdema-acute, 260 ; after iodide of potash, 92, 260; unusual forms, 77 ; orbital cellulitis, 269 ; tubage in, 166 ; carcinoma, 166

Csophagus-cicatricial stricture, I 18 ; diverticulum of, 257 ; electrolysis, 574 ; foreign body and asphyxia, 572; oesophagoplasty, I8; stenosis, 394 ; stricture of, 118 ; surgery of, 257

Original Articles-A Case of Laryngectomy (J. Solis-Cohen), 285: A Case of Late Hereditary Syphilis of the Nose, Pharynx, and Larynx (Ricardo Botey), r5o; A Case of Phthisis of the Larynx and Lungs, terminating in Epithelioma of the Larynx (Norris Wolfenden), 563 ; A New Intra-Tympanic Syringe (W. Milligan), 516; A Second Case of socalled Angina Ulcerosa Benigna (John Sedziak), 335 ; Aural Catheter Steam Sterilizer (John Bark), 289 ; Contribution to the Question of so-called Croup of the Nose (John Sedziak), 387 ; Massage in Diseases of the Nose and Throat (A. Kellgren), 207 ; Pharyngo. Mycosis (Henry Bixby Hemenway), 53 ; Remarks on Congenital Malformations of the Auditory Apparatus (George Heaton), I 48 ; Serious Symptoms arising from Retention of Nasal Discharge (Middlemass Hunt), I ; The El-ctric Light in Antral Disease, etc. (William Robertson), 64, 109, I54, 195; The Eustachian Bougie ( $\mathbf{W}^{+}$. Robertson), 3 ; The Eustachian Self-Inflator (Dundas Grant), 5; The Uses and Abuses of Cocaine (Arthur G. Hobbs), 5 I I ; Voice Training (Joal), 24I

Otitic epilepsy, 48

Oiitis--acute, treatment, r26, 270 ; excision of membrina tympani for, $4^{8}$; opening of mastoid for, 124; unusual inflammation after, 466

Ozæena, 14, 254
P.

Pachydermia laryngis, $8 \mathrm{I}$

Palate - tubercular ulceration of, $39 \mathrm{I}$

Papillomata (Grant), $2 \mathrm{I}$; of cords, 21 ; of ear, 80 ; laryngeal stenosis, I 20, 305 ; of tongue, 78 ; multiple, 21

Paralyses-abductor bilateral, 82 ; (bilateral) in aneurism of aorta, 37; bulbar lesions, 120; cases (123), unilateral, 23; experimental researches in, 120

Parotid gland, air-containing, $25^{6}$

Pemphigus - mouth, pharynx, and larynx, 17, 293, 526

Perichondritis aurieulie, I7I; of larynx, 26I

Phlegmon of pharynx, 299

Pilocarpin in deafness, 28

Pin sensations in throat, 572

Pneumonitis, experimental(Prudden), I 4

Poisoning by acid, 18 ; by antipyrin, II

Polypi-nasal, I4; radical treatment, II 6

R.

Reflexes of nose,ear, ctc. - asthenopia, I62 ; nasal, I4 ; surgical treatment, 164 Rest in treatment, $58 \mathrm{I}$

Reviews-Anæsthetics: Their Uses and Administration (D. W. Buxton), 508 ; Annual of the Universal Medical Sciences (Sajous), 507; Anatomic der Mundhöhle mit besonderer Beriicksichtigung der Zähne (Zuckerkandl), $5 \mathrm{I}$; A Practical Treatise on the Diseases of the Ear (D. B. St. John Roosa), 329 ; Atlas der Kehlkopf Krankheiten (Robt. Krieg), 561 ; Atlas der Krankheiten der Mund und Rachenhöhle (Mikulicz and Michelson), 325; Bacteriological Diagnosis (Eisenberg), 326 ; Book on the Physician himself and ihings that concern his reputation and success (D. W. Cathell), 594 ; Consumption: How to prevent it, and how to live with it (N. S. Davis, Junr.), 236 ; Cursus der Laryngoskopischen und Rhinoskopischen Technik (Avellis), 5 I ; Die Behandlung der Tuberkulose mit Tuberkulin in Hamburg und Leipzig (Klebs), 28I ; Die Erkrankungen der Nase, deren Nebenhöhlen des Nasenrachenramus und des Kehlkopfs (Carl Rosenthal, 282 ; Die Krankheiten der oberen Luftwege (Jurasz), 560; Die Therapeutischen Lieferungen des Jahres I89r (Pollatschek), 325; Die Unterscheidung der Gesangsregister auf 
Physiologischer Grundlage, mit besonderer Beriicksichtigung der Voix mixte (C. R. Hennig), 28I ; Essentials of Medical Electricity (Stewart and Lawrence), 326 ; Essentials of Bacteriology (M. V. Ball), 326 ; Experimentelle und Pathologisch-Anatomische Untersuchungen ueber Croup und Diphtherie (Middeldorpf und Goldmann), 283; Guide to the Administration of Anæsthetics (H. Davis), 283; Handbook of Diseases of the Ear, for the use of Students and Practitioners (Pritchard), 234; Handbuch der Inhalationen (Hankel), 49; Krankheits und Behandlungs Lehre der Nase und des Mundes, etc. (Bresgen), 50; Maladies de la Bouche et du Pharynx (A. Ruault), 503; Normale und Pathologische Anatomie der Nasenhöhle und ihrer Pneumatischer Anhange (Zuckerkandl), 599; On Hare-lip and Cleft Palate (Wm. Rose), 28I ; Pathologie und Therapie des Rachens der Nasenhöhlen und des Kehlkopfs (F. Massei), 49, 284; Sixth Annual Report of the State Board of Health, and Vital Statistics of the Commonwealth of Pennsylvania (Atkinson), 326; Syphilis in Ancient and Pre-Historic Times (F. Buret), 283; The Anatomical and Histological Dissection of the IIuman Ear in the Normal and Diseased Conditions (Adam Politzer), 144; The Mastoid Operation, including its History, Anatomy, and Pathology (S. E. Allen), 592; The Mediterranean Shores of America (Remondino), 327 ; The Micro-Organisms of the Oral Cavity, and the Local and General Diseases which are produced by them (W. D. Miller), 492 ; Transactions of the Nineteenth Annual Meeting of the American Laryngological Association, 507 ; Ueber die 2 tiologie der Strumitis (Favel), 280; Ueber die Anwendung der Anilinfärbestoffe bei Nasen, Halse und Ohrenleiden (Bresgen), 50 ; Vorlesungen iiber die Krankheiten des Kehlkopfs, der Luftröhre, der Nase und des Rachens (L. V. Schrötter), 49, 590 ; Vorlesungen uiber Ohrenheilkunde (Albert Bing), 278; Wann ist die Anwendung des Elektrischen Brenners in der Nase von Nutzen (Bresgen), 50.

Roaring in horses, 82

Rodent ulcer (Macintyre) and artificial face, 362

Rheumatism-acute in crico-arytenoid joint, I9I

Rhinitis-atrophic, 73, 254 ; etiology, I73; fibrinous, I4, I8, 73, 388; 575 ; pseudo-membranous, 254

Rhinoliths, $14,73,163,531$
Rhinoscleroma, 14, 302, 395 ; relation between it and chorditis inferior hypertrophica, 8 I

S. 530

Sarcoma of right lung, 84 ; palate, Septum - correction of deviation, 253; fracture of, II6; resection of, II5; perforation in typhoid, $34 \mathrm{I}$

Serum of dog in tuberculosis, 9

Sigmatismus, 255

Sinus thrombosis, 469

Sphenoidal-sinus dilatation of, 75

Stammering-after whooping cough, 217; discussion in British Laryngological and Rhinological Association, 219; followed by stuttering, 24; (Wyllie) 24

Stenosis-laryngeal, 83 ; bilateral, I1 5 ; naso-pharynx, 255; tracheal, 264,399

Stomatitis epidemica, 77,255

Syalolith in Wharton's duct, 76

Syphilis in children, 399; hereditary, I 50; laryngeal, 8I ; nasal, primary, 205

\section{T.}

Teeth-hygiene of artificial, I I7

Temporal bone-disease of (Pepper), 270

Thorax-surgery of, $25^{8}$

Thrush, 299

Thyroid gland-abscess of, 25 ; accessory, 307, 535 ; acute, 460 ; carcinoma of, 168 ; cysts of, 85 ; electrolysis in, 265; enucleation, 25 ; extirpation and its consequences, 26, 308 ; functions, 265,466 ; inflammation of, 265 ; mamma and female genitals, \&c., 25; physiology, 307 ; in rat, 583 ; in sheep, 460,584 ; regeneration of parenchyma, 25 ; removal, 265 ; study of, 25 ; treatment by implantacion (cat), 266 ; treatment with mercury, 265 ; treatment of soft by iodoform injection, 26 ; treatment by injection of thyroid juice, 265

Tongue-excision of, 39 , I1 17 ; depressor, 391 ; surgery of, 78 ; tuberculous ulceration, 39, I I 7 ; tumours of, 256; ulcer of, II8; wire ecraseur in excision, 117

Tonsil-accessory, 530 ; clinical and pathological changes in, 17 ; in health and disease, 90 ; pathology of inflamed, 79 ; pharyngeal, 186 ; primary malig. nant (Newman), 299 ; scirrhus of, 78 ; lingual-hypertrophy of, 215 ; instrument for removal, 256 ; syphilis of, 527 ; (Wyatt Wingrave) 213 
Tonsillitis, acute-salol in, I 12

Tornwaldt's disease, 184, 254

Tracheitis-hot inhalation, menthol, 128

Tracheocele, median, 23

Tracheotomy-in croup and diphtheria, 72 ; compared with intubation, I69; in diphtheria, 22 ; in infants, I2I ; in laryngeal affection, 22 ; for obstruction in pharynx, 165; without tube, I69; wounds infected with diphtheria, II 3

Tuberculin-cure with, 21 ; effect on pulse, 9; in laryngeal and pulmonary phthisis, $8 \mathrm{I}$; in lupus and tuberculosis, 9

Tuberculosis-creosote in, 454 ; reabsorption in, 82; tracheotomy in, 398 ; treatment of, 457,530
V.

Varix of ary-epiglottic folds, 2 I

Ventricles-erosion of, 176

Vertigo-aural, following injury, 173; of arterio-sclerosis, 409, 533 ; laryngeal, I68

Voice training-discussion British Laryngological Association, 215 ; (Joal) 24I ; (Solis-Cohen), 398

W.

Whooping cough (Ullman), I3 


\section{NAMES OF AU'THORS.}

Abbot II 4

Adler I68

Agroxamonte 277

Ajello 606

Albespy 117

Allen, C. W. 68

Allen, Harrison 90

Allen,Sam. Ellsworth 592

Allport, Frank 4I I

Alsburg 2.65

Althaus 220

Altmann 525

Andelfingen $27 \mathrm{~S}$

Anderson 458

Annandale, T. I 8

Armstrong 276

Arnheim I I

Asch 92, 276, 54 I

Asch, Morris J. 90, 92, $276,277,54 \mathrm{I}$

Ashhurst, 165

Ashby 520

Ast 534

Astier, C. 348,554

Atkinson 326

Aubert, C. 44

Avellis 23, $5 \mathrm{I}$

Baber, E. Cresswell 267, 393

Back, Jas. A. 580

Bacon, Gorhan 48, $55^{\circ}$

Baginsky, Adolf IO, II, I2, 22, 168, I74, 175, 249

Ball, J. B. 75

Ball, M. V. 326

Bandler $8 \mathrm{I}$

Barbier $7 \mathrm{I}$

Barclay 308

Bark, John 289

Barr 437

Barrett, J. WV. 589

Bates, W. H. I62, I73

Bauer 297

Baumgarten I15, 260, $26 \mathrm{I}, 263$

Bean, C. E. 324

l3eausoleil 497

13echtezeff 462
Beck, Carl 267, 528

Becker 165

Behnke, Emil 509

Belfield, Wm. T. 453

Beregskaszy, Julius 509

Beretta, C. 9

Berg 603

Betz 533

Beverley Robinson 70

Bevill, Cheves 168

Beyer 343, 344

Bezold, Fr. 30

Bing, Albert 278

Binniè, J. F. 15

Bishop, Seth Scott 490

Black, Alex. 270

Blake, C. J. 47, 404, 549, $55^{2}, 554$

Bloebaum 296

Bloodworth 456

Bluck 295

Bobone, T. 32

Bobroff 69

Bokai 250, 274

Bokay 583

Boland 346

Bonnier 536

Booker, W. D. 520

Booth, J. Mackenzie I22, 465

Bosworth 79, 91, 262, 277

Botey, Ricardo I26, I50, 254

Böttcher 2I

Boval 347

Bowen 305

Boylan, J. E. $47 \mathrm{I}$

Bradford 33

Braislin 255

Braun 573

Bresgen 50, .252, 361

Brieger 45, I43, I44, 179

Bristowe, J. S. II 2

Bronner, A. 73, 416, 432, $45^{8}$

Brown, Dillon 304

Browne, Lennox I60, 201, 203, 204, 33I, $365,380,428,437$

Brume 573
Bryan, J. H. 260, 324, 545

Buck, Albert H. 537

Bucklin, Chas. A. 246

Bull, I6 I

Buret 283

Burkart 580

Biirkner 8

Burnett, C. H. 48, 474, 475

Burroughs, Wellcome and Co. 509,510

Butts 254

Buxton, Dudley Wilmot 508

Caille 325

Campbell 572

Campbell, D. S. 394

Canizzaro, 265

Capart 342

Carpenter, J. G. 478

Carson, Edwin 260

Cartaz 33, 37, 183, 494, 555

Carter, J. M. G. 49I

Casselberry 92, I16, 479

Cathell, D. W. 594

Chapin 275

Chapman, S. Hartwell 324,539

Chappell, Walter F. 166, 256, 276, 453

Charazac 124,499

Chatellier, Henri I82, I83, I84, 233, 310, 349, $35^{8}$

Cheatham $16_{3}$

Cheval 67

Chiari $15,36 \mathrm{r}, 397,573$, 580

Cholewa 1 I 5,246

Church, Archibald 409

Clark, E. S. 269, 309, 402

Clarke, Bruce 57 I

Clarke, Ernest 82

Clarke, J. Jackson 75

Clasen 518

Clegg, IV. S. 40I 
Clegg, IV. T. II6, I2 I

Clive 165

Coghill, J. G. Sinclair 9

Cohnstädt, Ernest $5^{88}$

Collier 226

Collier, Mayo 367,377 , 380

Compaired 26I

Conitzer, $45^{8}$

Coolidge 39I

Corradi, C. 308 , 610

Cousins, J. Ward 8,122 , 161, 206, 208, 2II, 401

Cristiani 583

Croft 462

Dabney $25^{\circ}$

Da Costa 25 I

Dalby, Sir Wm. 269, 536

Daly 324

Daly, W. H. 577

Damiend 606

Daryens 496

Daubney $8 \mathrm{I}$

Daudois 31

Daver $25 \mathrm{I}$

Davidsohn 529

Davidson \& Davies 572

Davies 217

Davies 236, 283

Dean, H. Percy 468

De Blois, T. A. 544, 324

Delavan, D. Bryson 276, $277,324,538,54 \mathrm{I}$

Delie 321, 342, 346

Dellevie, Hugo 77

Delstanche 343, 345

Demme 14, 57 I

Dench, E. B. 126, 402, 4I I, 466

Desser, Leonard A. 394

Dionisio 608

Douglas I 3,277

Downie, $\mathrm{J}$. Walker $25^{8}$, 269

Drinkwater, H. 576

Drobnik 72

Dubler 299

Du Fouqeray, Hamon 464

Dunn, 298, 572

Dunn, John $5^{19}$

Editors of the British Merlical Journal 82

Editors of the Lancet 69 , I 7

Editor of the Medical Record 395

Editors of the Medical News 537

Edwards 460

Eeman 344, 345
Egidi, F. 247, 606, 609

Eiselberg 266, 584

Eisenberg, Jas. 326

Eitelberg 172

Elliott 524

Ellis 209, 430

Emerson, ]. B. 549

English, W. T. 258

Erb 570

Ewart, Wm. 583

Farlow, J. W. 544

Fasano 607, 609

Faulkner 296

Fanvel 493, 499

Felici 606

Fell, G. E. 248

Felsenthal 17

Ferras 497

Ferrer \& Clark 309

Ferreri 4IO

Fiaccarini 609

Ficano 609

Field 585

Fischer, Louis 250, 276, 325

Flasan 254

Flatalu 362

Florschiitz 295

Forcheimerf 255

Fougeray - Hamon du $442,464($ see $\mathrm{H})$

Fraenkel 84, 36I, I74, 176

Fraenkel, E. 252, 487, $57^{\circ}$

Frank 395

French 298

Freudenthal $I 12,454$

Freund 25

Friibstiick 302

Fulton 295

Fiirst 578,584

Galatti 583

Garel 317, 323, 498, 502

Garnault 360, 502

Garrigues, H. J. 525

Garrigou-Desarènes 495

Garzia 607

Gaucher 159

Gay, Geo. W. 6or

Gayton, W. 573

Gellé $34,35,40,43$, I8o, 187,3 r $3,359,437$

Gendre, laul Le 349

Gerster 257

Gibb 582

Gifford. H. 464

Giles, Anstey 306

Gilles 229

Glaser, Mercel 274

Glasgow 90
Gliick 22

Goodhart 73

Goodwillie, D. H. 177

Gordinier $5^{84}$

Goris 12

Gouguenheim 36,140 , I84, I92, 34I , 558, 597

Gradenigo 6IO, 6I I

Gradle, H. 405

Grant, J. Dundas 5, 2I, I6I, 210, 221 , 432, 433

Grayson, C. P. 533

Grazzi 604, 606

Green, J. T. $5^{8}$ I

Grönbech, A. C. 393

Grunwald 13, 116, 252, 256,305

Giintz $7 \mathbf{I}$

Guranowski 463

Guthrie, Leonard I 8

Guttmann 175

Gutzmann 255

Guye 406

I Iabermann 46,143

Habn 526

Hajek 18, 530

Hall, Haviland 528

Hamon du Pouqeray $44^{2}$

Hankel I 19

Hanslserg I 6

Harke 362

Harris, T. J. 534

Harrison, C. E. $5^{87}$

Haske, Th. 460

Hatch, W. K. 270

Hayes, T. A. 412

Heaton, Geo. 147, 536

Hecke I78

Heimann 27

Heineman, H. M. 408

Helferich 85

Hellier, J. H. 67

Hemenway, Henry Bixby 53

Hennig, C. R. 28I

Henoch I75

Hermes I40

Herringham 23

Fferroun, E. F. 273

Hertig 265

Heryng 82, 393, 394, 400,458

Heryng $\mathrm{d}$ Rejchman $45^{\circ}$

Hessler 74, I I 5,179

Hewetson 377

Hewitt, Frederic 245

Heymann 92, 175,176 , $361,526,582$

Heysinger 250

Hicguet 342, 343, 345, 497,499

Hill, Wm. 4I 8 
Hills, T. Hyde 28, 86

Hobbs, Arthur G. 5 I I

Hochenegg I8

Hochhaus 295

Hofmeister 307

Hogyes 274

Holden, E. H. R. 58I

Holmes, Gordon 167

Holt, E. E. 554

Holt 275

Holz 176,533

Horsley (London) 46I

Hovell, T. Mark 434

Hovorka $\mathbf{5 7 6}$

Hulke, J. W. 534

Hume, G. H. 120

Hunt, Middlemas I, 457, 630

Hutchinson, Jonathan 78 , 205

Hutinel 159

Ingals, Fletcher 324

Isaia 609

Jack, F. L. 55 I, 586

Jackson, Chevalier G. 39 I

Jacob, E. A. 77

Jacobi $276,277,325,602$

James, Prosser 266

Jankau, L. $27 \mathrm{I}$

Jarvis, Wm. 91, 246

Jayne $7 \mathrm{I}$

Jenson, P. C. 483

Joal 24I, 349

Joel 144

Johnson 603

Johnson, Walter B. 253, 487

Joins 163

Jones, Macnaughton $27 \mathrm{I}$

Jurasz 560

Kahn 294

Kahn 518

Kapper 26

Katzenstein 92, 264

Kaufmann 26, 188, 247

Kausch 532

Kayser 113

Keller 398

Kellgren 237

Kibbe, A. B. 396

Killian 162, 526

Kipp, Chas. J. 549

Kitchin, J. M. W. I65

Klebs 28I

Knapp and Bradford 33

Knapp, H. (N.Y.) 47, $467,472,549$

Knight, Chas. H. 245, $297,324,396,542,91$, 277
Knight, F. J., 324, 340

Kocher 257

Koch, Carl 298, 344

Köhler 26, 464

Koplik, H. 325, 52 I

Korangi 265

Körner 17

Kowallek 253

Kozsanecky 299

Krakauer, Alf. 5I, I4I, I44

Kramer 267

Kraus 456, 533

Krause 305

Kretschmann 140

Krezywicki 93

Krieg, Robt. 56I

Krieg I 5

Krowczynski 462

Krzywicki, Wm. 272

Kuchenbecker 297

Kugler 307

Kuhn 28

Kielenkampt and Nol. tenius 582

Kusselback 44

Küttner 22

Labus 606

Lacharrière $35^{8}$

Lacoarret 497

Lake, R. 86, 309

Laker 7o, 163, 397

Lamann I 12

Landgraf 94

Lane, Arbuthnot 3 Io

Lange 271,529

Langendrof 25

Langmaid, S. W. $53^{8}$

Laurent 346

Layrand 320

Lazarus 14

Leal 163

Leeman I 5

Legendre 159

Legroux 159

Lehmann I75

Lehotzky 25

Lemke 266

Lenzmann 8I

Leslie, Geo. 112

Lewin 93

Lichtenberg 3 I I 2 I

Lichtwitz 39, I87,306,315

Liewen 73

Lincoln 70

Linkenhold 120

Linsley, Joseph H. 456

Lloyd, Jordan $25,78,529$

Lodge, S. 82

Loeb I 70

Loeb, Hanau W. ${ }_{48}^{8 I}$

Loebinger 164
Loewe 177

Loewenstein 9

Loewenberg 140, I81, $\mathrm{I} 84,358,444$

Loewy 85

Longaker 25I

Lubet-Barbon 128, 186, 246, 498, 500

Lubliner I4, 83, 399

Lublinsky 92, 176

Luc 38,42 , I40, I62, I9I, I92, 320

Lunin 275

Lydston, F. 307

McBride, P. 75

MacCoy, Alex. A. 542

MacCoy 324

McGuire, C. M. 392

McIlraith, C. H. 572

Macintyre, John 362, $369,383,418$

Mackenzie, Morell 95

Mackenzie 92

Maclaren 85

McLeod $170^{\circ}$

Mallins, H. 251

Mandelstamm I7

Marage I92

Marano 607

Marocchi 609

Marsh 76

Martin, Alfred 128, 183

Martindale, F. E. 176 , $25 \mathrm{I}$

Masing 275

Massei, F. 49, 284

Massei 605, 608, 609

Massey $25 \mathrm{I}$

Massini 609, 611

Masters, J. A. I7

Matheson, Farquhar 219, 220

Maughan 587

Mayer, Wilhelm 25I

Medin 455

Meirhoff, E. 578

Meniere 233, 35I

Metzner 361

Meyer, 254

Meyer 166

Meyes, 305

Michelson, F. 262

Michelson 146

Middledorpf 283

Mikulicz and Michelson, T. 325

Miller, Frank E. I64

Miller, R. Shalders 409

Miller, W. D. 592

Milligan 17,87, 122, 16I, $205,206,207,211$, 407,516 
Mills, Chas. K. 173

Miot, 496

Mislavsky, Alexander A. 26

Moll 346

Mongardi, Romeo 27

Moos, S. 273, 407

Moritz 80, 582

Morra 609

Morrice, G. G. 456

Morison, Alexander 67 I 18,391

Morrison, A. C. 528

Morrison, Rutherford 526

Morton, C. A. I17, 39I

Moskowitz 302

Mosler 26

Mossin 275

Moure 323, 348, 496, $498,503,518$

Mules, P. 82, $53^{2}$

Mulhall 90

Mündler, W. 263

Munger, Carl 519, 573

Munke 20

Mushold 93

Mygind, Holger 337

Nabias and Sabrayés $55^{8}$

Natier 501, 502

Neumann 17, 175

Nevins, Arthur E. 255

Newcomb, Jas. E. 276 , $470,527,533$,

Newman D. I 8 , 299

Nicolai 609

Nicoll, James H. 263

Nitsche I 5

Noquet 50 I

Norbury 392

North, John 487

Northup 603

Nothers, J. J. 402

Nutt 25I

Nuvoli 606, 609

Oatman, E. 246

O'Dwyer, J. 247, 599

Onodi I 20

Oppenheimer 575

O'Reilly, G. J. 265

O'Roe 324

O'Toole, C. 484

Otto 175

Owen, Edmund I 18

Ozegowski 455

Packman, A. I I'

Padiitcheff, Vladimar A. 20

Paget, Stephen 524

Palma 535

Paltauf 25, 86
Papadapoulos, M. 43

Paris Correspondent Lancet 68

Parisot $7 \mathbf{I}$

Parker, Rushton 172

Pegler 2 IO

Penrose, Geo. R. 454

Pepper, A. J. 270, 589

Percepied $44^{\circ}$

Pessar, L. A. 254

Peters 299

Petersen 264

Philipp 113

Phillips, Wendell C. 276

Pilcher 60I

Podbelsky 307

Pollard, Bilton 257

Pollatschek 325

Poli 3r, 609

Politzer, Adam I44, I99, 354

Polo 1 25, 321

Pomeroy, Oren D. 546

Pooley, Thos. R. I7 I

Poppert I 6

Potiquet 129, 182, 184, 3I3, 596, 597

Poyet 498

Prescott and Groldthwait I69, I99

Pritchard, Urban 28, 234, 268

Prudden, Mitchell I 14

Rabot \& Philipp II 3

Radyiszewski 459

Ragoneau I 57

Randall, B. A. 48, 465, $480,548,553$

Rankin, R. 324

Rauchfuss 22

Rauge, Paul 3 I8

Rause I3

Ray, J. M. 48

Rebitzer I 66

Reeve, R. A. 554

Rehn 25I

Reiersen, A. 455

Reinhard 89

Reinhold 14

Remondino 327

Rethi 580

Retter, P. $\times 74,256$

Reverdin \& Buscarlet 57 I

Ribbert 25

Rice 90, 302, 394

Rice, C. C. 324,543

Richards, G. A. I 20

Richardson, C. W. 464, 493

Richardson 166,493

Ritter $\mathbf{5 2 4}$

Roaldes $30_{3}, 539$
Roberts $25 \mathrm{I}$

Robertson, R 9

Robertson, Wm. 3, 64, 81, I09, I 17, I 54, I95, $431,532,568$

Robinson, Beverley 262, 277, 301, 324, 541, 587

Roe, John O. 90, I77, $442,544,595$

Rohrer 163

Roman von Baracz 23

Roosa, D. B. St. John $327,533,551$

Root 83

Rose, Wm. 28I

Rosenberg 176, 256

Rosenberg 93

Rosenthal, Carl 25r, 282, 299

Rossi, E. de 273

Rougier 322

Rousseau 323, 344

Rozanzweig R. H. 8o

Ruault $36,44,135$, I40, I84, I87, I92, 350, 392, 503

Rutten 344

Ryan \& Barrett 589

Saint Hilaire 35, I93

Sajous 324,507

Salinger i 2

Sandford I6I, 2II, 2I5, 365,423

Sane y Molist 122

Sattler I2

Sauer 163

Schafer 306

Schalck, E. 253

Scheibe, Arno 46, 272 , 404, 406

Scheier 93, I76

Scheinmann 21, 73, 93, 175, 176, 362, 399

Schemm 295

Scheppegrell 574

Scheppegrell, W. 518

Schiffers I 5, I9, 341, 342

Schlatter 296

Schlichter 249

Schmidt, Moritz I 16

Schmidthuyzen 362

Schmiegelow, E. 30, 304, 401,405

Schmolka 76

Scholefield, R. E. I67

Schroeder 246

Schrötter 49, 417, 590

Schrevens IO

Schuster 344

Schwartze 140, I44

Schwarze and Schulze 26

Schweinitz 252, 297 
Scott Bishop 490

Sedziak, John 335, 387, 5 I 9

Seibert 276

Seiss, Ralph W. 473

Serks 275

Seton, B. G. 534

Shaw, E. A. 580

Sheppard, J. E. 468

Shields 265

Shield, A. Marmaduke, 268,469

Shurley 91 , I 6

Siebenmann I4, 140

Siegil 76

Simon, F. 417

Simon, Jules 158

Skerritt, E. Markham 9

Smith, Lewis J. 455,522

Smith, Chas. I I3

Smith, $5^{89}$

Smith, J. A. 17

Smith, G. Cockburn 69

Soble, M. D. 68

Socin 23

Sokolowski 79, 397

Solis-Cohen 92, 285, 324, $398,400,531$

Solly 75

Spalding, J. A. 459, 463

Spanton, W. D. 85

Spencer 246

Spishamy 534

Spohr 53I

Spratling, L. W. 30

Spronk II 3

Srebrny and Bujwid 395

Stacke 87

Stale, Chas. 78

Stamm 254

Starck 575

Stein 294, 398

Steinthal 16

Stern 298

Stetter 588

Stewart, Anderson 158

Stewart, D. D. and Lawrence, E. S. 326

Stewart, Donald 120, 206, 398, 412, $45^{8}$

Stewart, T. P. 259

Stewart, W. R. H. 269

Stickler 69

Stierlin 266

Stiller 267

Stillman, Frank L. 163

Stimmel i 44

Stimson 276

Stoker 206, 213

Straus 399

Strazza 607

Strelitz I I

Strübing $21,70,267$
Suarez de Mendoza 323, 348 , 501

Suchannek 277

Suckling, C. W. I 20, 400

Sutherland. G. A. I69

Sutphem, T. Y. 550

Swain, H. L. 543

Swinburne, R. E. 585

Symonds 457

Szalardy 274

Szenes 27, 142, I 43

Szoldoski 8

\section{Tangl II}

Targett, J. H. 85

Tavel 280

Taylor 457

Teets 165

Theobald, Saml. 48, 49, $55 \mathrm{I}$

Thiem 175

Thorington, J. 527

Thornbury 523

Thorner 299, 528

Thost 362

Thrasher, A. B. 492

Thursfield 455

Tietze 170

Tilnig 527

Toeplitz, Max 256, 409

Tooth, Howard $25 \mathrm{I}$

Townsend 163

Truckenbrod, C 45, 408

Trans. of the Igth Annl. meeting, Amer. Laryn. Assn. 507

Trautman 25I

Treitel 24, I75

Trevelyan 73

Trifiletti 605

Troje 174

Tubby, A. H. 87

Turnbull $3^{8} 3$

Turner, F. C. 84

Turner 250

Tymowsky 262

Uchermann, V. 410

Ullmann 13

Vacher 321

Vali, Ernst I 7 I

Vaughan, J. C. 173

Verstracten, 12

Villon 112

Virchow I75

Von Doukoff, E. I69

Voss 274

Vulpius 8

Wagner $73,74,90,121$, $264,343,362$

Wagnier 322, 343, 579
Walb I43, I 44

Wallace, D. 121

Warden 382

Waren, J. Collins'535

Warren 460

Wassermann $40 \mathrm{I}$

Watkins 295

Watson, W. Spencer 14, 575,579

Waxham, F. E. 12, 21, $22,477,602$

Weir, R. F. 253

Welch, Flexner I I3

West, S. 457

White, Digby I 8

White, I. Blake 245

White, J. R. $45^{6}$

White, Joseph A. 486

Whiting 164

Wiesmann 266

Wiesner 25

Williams, Watson 2I, 432

Williams, W. Roger I I7, 39 I

Williams, 249

Villiams, Alfred 457

Wilson, T. Stacey I9

Wilks, Samuel 258

Wingrave, Wyatt I6I, $213,215,368$

Winters 275

Wissing, John 455

Witthauer 394

Woakes 577

Wodin 344

Wodon I 5

Wolf, Julius 120, 401, 308

Wolfenden, Norris 290, 563

Wolfenstein, J. $5^{85}$

Wolfler 86

Wollen, G. V. $4^{81}$

Wright 167

Wright, Jonathan 90, I 12 , $472,91,324,540,542$

Wroblewsky $16,75,392$

Würdemann $32,463,489$

Wyllie 24

Wynne, E. T. 72

Yeo, Burney 8

Yeo, Gerald 273

Zarnikow 16, 174

Zeman 256

Ziem 162, 188, 252, 254, 256, 518, 529

Zimmermann, Chas. 269

Zuckerkandl $5 \mathrm{I}, 590$

Zuffinger 2I, 8I

Zurllinger 274 


\section{Medicated Throat Pastilles,}

\section{Manufactured by Allen \& Hanburys.}

THESE Pastilles are introduced as an improvement on the ordinary hard, rough, and angular Lozenges, fragments of 1 which often irritate the nouth when in an inflamed or ulcerated condition. Having as their basis Pate de Jujube, they are sofc and demulcent in themselves, whilst their rounded form and, in most instances, agreeable flavour make them valuable substitutes for the Lozenges now in common use.

I. HORPHIA. (I-40th of a grain.)

Adult dose: From 6 to ro daily.

2. I P E C A C U AN HA. Readily taken by children. These pastilles are of the same strength as the B.P. lozenges.

3. M $O R$ P I $A$ and I PECACUANHA. (I-4oth grain Morph., and $\downarrow$ grain I pecac.)

Adults may take one every two, three, or four hours.

4. COMPOUND MORPHIA and IPECACUANHA. A more active remedy than No. 3 . (I-4oth grain Morph., I-5th Ipecac., I-5th Squills, \&c.)

For adults: One every two, three, or four hours.

5. OPIUM and BELLADONNA. An agreeable substitute for, and containing the same amount of opium as, the lozenges of the British Pharmacopreia.

6. ACONITE. Each Pastille equivalent to half a drop of the B.P. Tincture.

Adult dose : One every two, three, or four hours.

7. COMPOUND CAMPHOR OP YOICE.

Adult dose : From three to six or eight at intervals during the day.

8. CHLORATE of SODA. May be taken whenever the throat is uneasy.

10. BENZOATED YOICE. Useful to public speakers, \&c. Less active than the Compound Camphor.

One or two may be taken shortily before any exertion of the voice.

11. CHLORATE of POTASH. A more agreeable form than the lozenge of the Pharmacopoia. Dose : From 6 to 12 daily.

13. RHATANY. Astringent.

Dose : 6 to 12 daily, at intervals.

14. TANNIN. Astringent, and of the same strength as the Tannic Acid Lozenges B.P.

15. CARBOLIC ACID. Antiseptic and stimulant.

Dose: One to be taken every two, three, or four hours.

16. BROMIDE of EMMONIUM.

Dose: One every two, three, or four hours.

17. CHLORATE of POTABH and BORAX. Containing these two useful remedies in combination.

18. BORAX.

ose : One to be taken frequently.

Dose : One to be taken frequently.

19. CHLORIDE of AMMONIUM. Expectorant.

Dose : One to be taken frequently.

20. GUAIACUM. (Two grains of guaiacum in each.)

Dose : One every two hours.

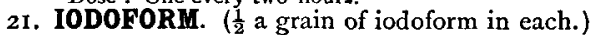

Dose : One every two, three, or four hours.

22. RED GUM. Astringent.

Dose : One may be taken frequently.
23. E U C A L Y P T U S. Antiseptic and stimulant.

Dose : One to be taken frequently.

24. COCAINE. (I-Ioth and I-2oth grain.)

Sedative to the mucous membrane.

Dose: One every three or four hours.

25. SEDATIYE and ASTRINGENT. (Morphia I-4oth grain. Red gum 2 grains.)

Dose : One every two or three hours.

26. CODEINE. (I-8th grain Codeine.) Sedative. Dose: Six may be taken during the day.

27. COMPOUND EUCALYPTUS. (Red Gum, Chlorate of Potash, and Cubebs.)

28. COMPOUND GUAIACUM. (Guaiacum, Chlorate of Potash, and Red Gum.)

29. COMPOUND RHATANY. ( 2 grains of Extract of Rhatany and $I$ - Ioth grain of Hydrochlorate of Cocaine.)

Dose: From four to six a day.

30. BORACIC ACID. (I grain.)

3I. RED GUM and COCAINE. (Containing Red Gum and I-2oth gr. of Hydrochlorate of Cocaine.)

32. RED GUM and CHLORATE of POTASH. Astringent.

33. RHATANY and CAPSICUM. (2 gr. of Extract of Rhatany.)

Dose: From four to six a day.

34. TEREBENE. (2 minims of Terebene.)

Dose : From four to six a day.

35. JABORANDI. ( $\frac{1}{\mathrm{gr}}$. Extract in each.)

36. PUMILIO PINE. Stimulant to the throat. (I minim in each.)

37. LETTUCE and BORAX. (Ext. Lactucæ gr. $\frac{1}{3}$, Pulv. Boracis gr. ij. in each.)

38. COCAINE, CHLORATE of POTASH and BORAX. For tickling and irritation of the Throat.

39. LACTIC ACID. (2 minims of lactic acid in each.)

Dose : One to be taken frequently.

40. COCA. (Containing $2 \frac{1}{2} \mathrm{gr}$. of Coca Extract in each.)

Dose : One every three or four hours.

4 I. EUCALYPTUS OIL. Antiseptic and stimulant. Dose : One every two or three hours.

42. KOLA. Stimulating and tonic.

Dose : One may be taken frequently.

43. MENTHOL. ( 1 -eoth grain in each.) Stimu. lant and antiseptic.

Dose : One when required.

44. MENTHOL and COCAINE. (I-2oth grain in each in a pastille.) Stimulant, antiseptic, and sedative.

Dose : One may be taken three or four times a day.

Put up in Fin Boxes, and sold at 1s. (Retail); als; 1lb. Bottles at 3s. each to the Profession, bottles returnable at 68. per dozen.

\section{Allen \& Hanburys, London.}

Offices,Laboratories $\mathcal{E}$ Warehouse-Bethnal GreEn, E. City House-Plovgh Court, Lombard St., E.C. 


\section{THE MEDICAL ANNUAL, 1893.}

A Complete Work of Reference for Medical Practitioners, alphabetically arranged, the conjoint labour of British, Continental, and American authorities, including Practical and Original Articles on every department of Medicine, Surgery, and Therapeutics.

Synopsis of CONTENTS, AND EuITORS AND CONTRIBUtORS FOR 1893 :

THE DICTIONAIX OF NEXY REMEDIES.

Containing a Complete Report on all new Therapeutic agents introduced during the year, with Clinical Indications for their use, and a

Rexievy of Therapeutics,

By Prof. H. A. HARE, M.D., Philadelphia, Prof. of Therapeutics in the Jefferson Med. Coll., and Editor of "The Therapeutic Gazette."

IFE DICTIONAIR OF NEW TIEATMENT.

A Complete Index of Diseases, showing the latest Therapeutic recommendations (Medical and Surgical).

ABDOMINAL SURGERY. Illustrated.

By Prof. A. W. MAYO ROBSON, F.R.C.S.

BLADDER AND URETHRA, RENAL SURGERY.

By E. HURRY FENWICK, F.R.C.S., Surg. St. Peter's Hosp. for Urin. Dis.

BRAIN AND SPINAL SURGERY. Illustrated.

Surgical Treatment-

By W. THORBURN, F.R.C.S., B.S.

Orthopedic Treatment-

BY ROBERT JONES, F.R.C.S. ;

JOHN RIDLON, M.D., Chicago. CANCER.

By W. H. ELAM, F.R.C.S., London.

\section{CHILDREN'S DISEASES.}

By Prof. HENRY DWIGHT CHAPIN, M.A., M.D., New York.

CHOLERA.

Notes on Epidemic in Kashmir, I892-

By A. MITRA, L.R.C.P., Chief Medical Officer.

Notes on Epidemic in Russia, $1392 \rightarrow$

By RICHARD SISIEY, M.D., Russia.

Notes on Epidemic in Hamburg, $1892-$

By F. REICHE, M.D., Phys. New Gen. Hosp. Hamburg.

Is Quarantine useful as a Preventive of Cholera?

By C. N. MACNAMARA, F.R.C.S.

Treatment of Cholera-

By SIR GEORGE JOHNSON, M.D., F.R.S.

Cholera Infantum-

By E. MEINERT, M.D., Dresden.

DISORDERS OF THE DIGESTIYE SYSTEM.

ILLUSTRATED.

Part I. $\rightarrow$ By Prof. C. A. EWALD, M.D., Berlin.

PART II.-By Prof. DUJARDIN-BEAUMETZ, M.D., Paris.

EAR AND NOSE. ILLUSTRATED.

By J. DUNDAS GRANT, M.A., M.D., F.R.C.S., Surg.

Cent. Lond. Throat and Ear Hosp.

EYE DISEASES.

By W. LANG, F.R.C.S,

HEART, DISEASES OF.

By FRANK W. JACKSON, M.D., New York.

INDIAN DISEASES. ILLUSTRATED.

By Surg.-Major ALEX. CROMBIE, M.D., L.R.C.S., Calcutta.

SANITARY PROGRESS FOR THE YEAR 1892-(I/lustrated).

By J.OSEPH PRIESTLEY, B.A., M.D., D.P.H., Medical Officer of Health, and Public Analyst for Leicester. PROGRESS OF PHARMACY.-NEW INVENTIONS.-BOOKS OF THE YEAR,-\&o, \&.
THE LARYNGOSCOPE. Practical Hints on the Use of. With 9 Coloured Illustrations.

By P. WATSON WILLIAMS, M.D. Lond., Throat Phys. Bristol Royal Infirm.

MEDICINE, GENERAL.

By F. J. WETHERED, M.D. Lond., M.R.C.P. NERYOUS SYSTEM.

By Prof. G. M. HAMMOND, A.M., M.D., New York. OBSTRUCTIYE JAUNDICE.

By VAUGHAN HARLEY, M.D., M.R.C.P., Phys. Inst. Leipsig.

OBSTETRICS AND UTERINE DISORDERS. ILLUSTRATED.

By WM. J. SMYLY, M.D., F.R.C.S.I, Mas. Rot. Hosp. Dublin; and JOHN H. GLEN N, M.B., B.Ch. M.A.O., Assis. Mas, Rot. Hosp.

Extra-Uterine Gestation-

BY JOHN W. TAYLOR, F.R.C.S.

ORTHOPEDICS. ILLUSTRATED.

By ROBERT JONES, F.R.C.S. Ed.; and

JOHN RIDLON, M.A., M.D., Chicago.

PERITYPHLITIS.

By Prof. E. SON NEN BURG, M.D., Berlin.

PULMONARY DISEASES.

By R. SHINGLETON SMITH, M.D. Lond., B.Sc. F.R.C.P.

RENAL AND URINARY DISEASES.

By Prof, ROBT. SAUNDBY, M.D., F.R.C.P.

SKIN DISEASES.

By T. COLCOTT FOX, B.A., M.B., F.R.C.P.

SURGERY, GENERAL. ILIUSTRATED.

By FREDERIC S. EVE, F.R.C.S.

TESTICULAR EMULSION : Method of Administration.

By Prof. BROWN-SEQUARD, M.D., Paris.

TUBERCLE : ITS NATURE AND CAUSATION.

By M. ARMAND RUFFER, M.A., M.D.

URETHROSCOPY. With 15 Coloured Illustrations.

By E. HURRY FENWICK, F.R.C.S.

YARICOSE VEINS. ILLUSTRATED.

Treatment by Ligature of Saphenous Vein-

By Prof. E. TRENDELENBURG, M.D., Bonn.

Bristol: JOHN WRIGHT \& CO. London: SIMPKIN, MARSHALL \& C0., Limited. 


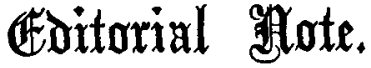

\section{OUR NEW DEPARTURE-OTOLOGY.}

IT has been determined, after great consideration, to widen the scope of this Journal by including in its matter the subject of Otology. We have been led to do so for several reasons. One of these reasons is certainly not any want of appreciation of our paper in its present condition, as we have every reason to be gratified with the increased demand for it during the present year. On the other hand, it is well known that the specialities of Rhinology and Otology are as closely associated as those of Rhinology and Laryngology, and it has seemed regrettable that a branch of the healing art so closely intertwined with those we have hitherto exclusively cultivated should be kept apart and allowed, as far as we are concerned, to wither. Many of our readers are otologists, and we venture to think that we are about to supply wants which many have expressed and many more have felt. Apart from the American "Archives of Otology," we believe there is no journal in the English language which gives an exhaustive review of the science referred to. What we offer to do is, to present our readers with such original articles, abstracts and reviews, as may enable them to keep abreast of the state of knowledge of the ear and its diseases. Our co-editor, Dr. Dundas GRANT, has accepted the responsibility for the fulfilment of this promise, and we have every confidence that the hopes of the editing committee will be realised, and the requirements of a large circle of readers satisfied.

This is the first number which contains the section on Otology. 


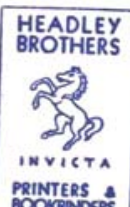


